\title{
Identification of thyroglobulin domain(s) involved in cell-surface binding and endocytosis
}

\author{
S Siffroi-Fernandez, F Delom, M-C Nlend, J Lanet, J-L Franc \\ and A Giraud
}

INSERM U-555 and Laboratoire de Biochimie Endocrinienne et Métabolique, Faculté de Médecine, Université de la Mediterranée, Marseille, France

(Requests for offprints should be addressed to A Giraud, INSERM U-555, Faculté de Médecine, 27 boulevard J Moulin, cedex 5, 13385 Marseille, France;

Email: Annie.Giraud@medecine.univ-mrs.fr)

(M-C Nlend is now at University of Miami, Pulmonary Division (R-47), 1600 NW 10th Avenue, Miami, Florida 33136, USA)

\begin{abstract}
Thyroglobulin $(\mathrm{Tg})$ binds to cell surfaces through various binding sites of high, moderate and low affinity. We have previously shown that binding with low to moderate affinity is $\mathrm{pH}$ dependent, selective, but not tissue specific. To identify the regions of $\mathrm{Tg}$ involved in this cell surface binding, we studied the binding of ${ }^{125}$ I-labeled cyanogen bromide peptides from human $\mathrm{Tg}$ to cell surfaces of thyroid cells (inside-out follicles) and of $\mathrm{CHO}$ cells. Electrophoretic analysis of cell homogenates after binding of native or of reduced and alkylated ${ }^{125}$ I-labeled peptides showed that three peptides, P1, P2 and P3, were always associated with the cells. Sequence analysis allowed the identification of P1 (Ser-2445 to Met-2596 or Met-2610) and P2 (Phe-2156 to Met-2306). P3 proved to be a mixture of several peptides among which two were identified: P3-1 (Cys-1306 to Met-1640) and P3-2 (Cys-2035 to Met-2413) which includes P2. P1, P2 and P3-2 are entirely (P1) or partly (P2 and P3-2) located in
\end{abstract}

the C-terminal domain of $\mathrm{Tg}$ homologous with acetylcholinesterase. The smallest peptides, P1 and P2, were purified by preparative electrophoresis. They both displayed strong binding properties towards cell surfaces. Inhibition experiments of ${ }^{125} \mathrm{I}$-labeled $\mathrm{Tg}$ binding by $\mathrm{P} 1$ or P2 indicated that they were involved in Tg binding to cell surfaces. All the other peptides tested for their binding abilities were either not or only poorly involved in $\mathrm{Tg}$ binding to cell surfaces, which suggested that P1 and P2 are major $\mathrm{Tg}$ sites of binding to cell surfaces. These two peptides are not involved in the binding of $\mathrm{Tg}$ to the known Tg 'receptors' described in the literature, to which recycling, transcytosis and regulation functions have been ascribed. Thus they are potential tools to identify cell surface components involved in the process of $\mathrm{Tg}$ endocytosis leading to lysosomal degradation.

Journal of Endocrinology (2001) 170, 217-226

\section{Introduction}

Thyroglobulin (Tg), a large glycoprotein (660 kDa) produced by thyrocytes, is the prothyroid hormone. After being synthesized and undergoing post-translational modifications, $\mathrm{Tg}$ is secreted into the lumen of thyroid follicles where it undergoes tyrosyl iodination and coupling of some iodotyrosyl residues: these reactions lead to the formation of tri-iodothyronine and thyroxine. Thyroid hormone secretion requires $\mathrm{Tg}$ to be endocytosed, transported to the lysosomes and enzymatically hydrolyzed, after which thyroid hormone release occurs (Bjorkman \& Ekholm 1990).

$\mathrm{Tg}$ endocytosis occurs partly through fluid phase uptake and mainly through adsorptive micropinocytosis, which requires Tg binding to cell surfaces (Lemansky \& Herzog 1992). Thyroglobulin interactions with thyroid membranes have been observed for several years (Consiglio et al. 1981). Several 'receptors' liable to mediate Tg binding to cell surfaces have been recently described: a receptor able to bind asialoagalacto $\mathrm{Tg}$ at acidic $\mathrm{pH}$ levels (Miquelis et al. 1987); the protein disulfide isomerase (PDI) (Mezghrani et al. 2000); histone H1 (Brix et al. 1998); heparin (Marino et al. 1999a); megalin (Zheng et al. 1998, Marino et al. 1999b); and rat hepatic lectin subunit of a rat asialoglycoprotein receptor (ASGPR) (Pacifico et al. 1999, Ulianich et al. 1999). Some functions have been associated with various 'receptors': megalin was shown to be involved in transcytosis (Marino \& McCluskey 2000, Marino et al. 2000); PDI was associated with Tg recycling (Miquelis et al. 1987, Mezghrani et al. 2000); histone H1 was involved in circulating Tg uptake by macrophages (Brix et al. 1998); and a role was proposed for ASGPR in feedback regulation, ASGPR preventing thyroid-restricted gene expression under follicular $\mathrm{Tg}$ binding (Pacifico et al. 1999, Ulianich et al. 1999). However, none was associated with $\mathrm{Tg}$ binding and targeting to lysosomal degradation in thyroid cells. 
One major obstacle in studying the binding of $\mathrm{Tg}$ to cell membrane components is the size and complexity of the molecule. The Tg gene has been cloned and mapped in several species including humans (Mercken et al. 1985, Malthiery \& Lissitzky 1987, Caturegli et al. 1997, Van de Graaf et al. 1997). It is formed of several juxtaposed domains, and is thought to result from the fusion between one gene consisting of several different repeat units and possessing the main hormonogenic site, and another gene on the C-terminal side, resulting from the duplication of a primitive esterase gene, even before the divergence between vertebrates and invertebrates occurred (Takagi et al. 1991). The C-terminal part of the $\mathrm{Tg}$ gene has secondary hormonogenic sites and no esterase activity. Some of these domains show various degrees of homology with numerous proteins (Takagi et al. 1991, Molina et al. 1996a). This has led to various hypothetical functions (Swillens et al. 1986, Molina et al. 1996b) being attributed to $\mathrm{Tg}$ domains, which are thought to be mediated by $\mathrm{Tg}$ interactions with specific ligands. This accounts for the large number of proteins able to bind $\mathrm{Tg}$.

In a previous study, we established that the thyrocyte apical membrane binding and internalization of $\mathrm{Tg}$ were selective, i.e. more efficient than membrane binding and internalization of various control proteins (Giraud et al. 1997). We also observed that the Tg binding and internalization were not tissue specific, which indicated that the binding selectivity displayed was an intrinsic property of the Tg molecule (Giraud et al. 1997). This prompted us to attempt to identify the domains of Tg involved in the binding of the molecule to the cell membranes. To circumvent the problems caused by the complex structure of the molecule, one possible approach is to cut the molecule into pieces and to study the binding activity of the fragments. This approach has been successfully used to identify a recycling receptor-binding peptide (Mezghrani et al. 1997), a rat asialoglycoprotein-binding domain (Montuori et al. 2000) and an immunodominant region of Tg (Duthoit et al. 2000).

In the present study, we found that two peptides located in the C-terminal part of the molecule express strong membrane binding and internalization properties and are involved in whole $\mathrm{Tg}$ binding. These peptides were not involved in the binding of $\mathrm{Tg}$ to its already known 'receptors' to which Tg recycling, transcytosis or regulation functions were ascribed, and are potential tools with which to characterize membrane components involved in the endocytosis of $\mathrm{Tg}$ molecules targeted to lysosomal degradation and hormone release.

\section{Materials and Methods}

\section{Materials}

Culture media were from Sigma Aldrich Chimie SARL (Saint Quentin Fallavier, France) and from Gibco BRL,
Life Technologies (Cergy Pontoise, France). IgG, bovine serum albumin, agarose and amphotericin B (fungizone) were from Sigma Aldrich Chimie SARL. Penicillin and streptomycin were from Life Technologies. Fetal bovine serum (FBS) was from Valbiotech (Paris, France). Protease inhibitor cocktail tablets (Complete) were from Boehringer Mannheim SA (Meylan, France). ${ }^{125} \mathrm{I}-\mathrm{NaI}$ was from Cis Bio International (Gif sur Yvette, France). Aquaseal (water-soluble siliconizing fluid) was from Pierce Chemical Co. (Rockford, IL, USA). Centricon YM-10 and Ultrafree-15 were from Millipore Corporation (Bedford, MA, USA). Bio-Gel A-5M column was from Bio-Rad SA (Marnes-la-Coquette, France). Sephadex G-200 column was from Amersham (Orsay, France).

\section{Cell cultures}

Porcine thyroid cells were isolated from fresh thyroid glands by discontinuous trypsin-EGTA treatment (Chambard et al. 1981). Inside-out follicles were obtained as described previously (Espanet et al. 1992, Giraud et al. 1997). Briefly, the cells $\left(10^{6}\right.$ cells $\left./ \mathrm{ml}\right)$ in Dulbecco's modified Eagle's medium (DMEM) containing antibiotics and fungizone and supplemented with $10 \%$ FBS were cultured in the form of unstirred suspensions in polystyrene dishes not treated for tissue culture and coated with $1 \%$ agarose. They were maintained at $36{ }^{\circ} \mathrm{C}$ in a watersaturated $95 \%$ air- $5 \% \mathrm{CO}_{2}$ atmosphere. The cultures were used after 10-12 days (by then, most of the cells had formed inside-out follicles). Twenty-four hours before each experiment, $10^{-4} \mathrm{M}$ dibutyryl adenosine- $3^{\prime}, 5^{\prime}-$ cyclic-monophosphate was added to the culture medium.

Madin-Darby canine kidney (MDCK) cells were grown in DMEM supplemented with 10\% FBS and antibiotics on Petri dishes treated for tissue culture. After reaching confluence, they were suspended by applying a trypsinEDTA treatment as described by Giraud et al. (1997) and seeded on Petri dishes not treated for tissue culture and coated with $1 \%$ agarose. They were then grown as unstirred suspensions for 24-72 h before use. They formed large aggregates and occasionally follicle-like structures.

Chinese hamster ovary $(\mathrm{CHO})$ cells were handled like MDCK cells except that the growth medium was Ham's F-12 medium supplemented with 10\% FBS and antibiotics. When grown in unstirred suspensions, they form small loose aggregates.

\section{Isolation of human $\mathrm{Tg}(\mathrm{hTg})$}

A human thyroid gland from a patient with a colloid goiter was obtained by thyroidectomy. After pathological examination, the gland was frozen and lyophilized. About $1 \mathrm{~g}$ lyophilized gland was fragmented and suspended in $0 \cdot 1 \mathrm{M}$ phosphate buffer, $\mathrm{pH} 7 \cdot 2$, for $15 \mathrm{~min}$. After filtration on gauze, the supernatant of the thyroid homogenate was salted out $(1 \cdot 8 \mathrm{M}$ phosphate buffer, $\mathrm{pH} 7 \cdot 2)$. After 
centrifugation, the precipitate was dissolved with water, dialyzed against $50 \mathrm{mM}$ phosphate buffer, $\mathrm{pH} 7 \cdot 2$, and chromatographed on a Bio-Gel A-5M column $(100 \times$ $5 \mathrm{~cm}$ ) as previously described (Marriq et al. 1977). The fractions corresponding to $19 \mathrm{~S} \mathrm{Tg}$ were pooled, dialyzed and lyophilized. This $19 \mathrm{~S} \mathrm{Tg}$ was poorly iodinated.

\section{Preparation of cyanogen bromide $(\mathrm{CNBr})$ peptides}

$\mathrm{CNBr}$ peptides from iodine-poor $\mathrm{hTg}$ were prepared and fractionated as described by Marriq et al. (1986). In brief, hTg was treated with $\mathrm{CNBr}$ and the resulting $\mathrm{CNBr}$ peptides were filtered on a Sephadex G-200 column in $1 \mathrm{M}$ propionic acid. Five fractions (I-V) were collected, dialyzed and freeze-dried.

\section{Preparative electrophoresis}

$\mathrm{CNBr}$ peptides of fraction III were further separated by performing preparative SDS-PAGE electrophoresis using a model 491 Prep Cell preparative electrophoresis apparatus (Bio-Rad SA, Marnes-la-Coquette, France). The gels (running gel: 15\% acrylamide; stacking gel: 4\% acrylamide) were prepared according to the manufacturer's instructions. Peptides were solubilized in the sample buffer described by Laemmli (1970) and reduced by heating them for $5 \mathrm{~min}$ at $100{ }^{\circ} \mathrm{C}$ in $5 \% 2$-mercaptoethanol. They were loaded on the stacking gel and electrophoresed at $40 \mathrm{~mA}$ constant current for $9 \mathrm{~h}$. Fractions $(2 \mathrm{ml}$, elution rate $1 \mathrm{ml} / \mathrm{min}$ ) were collected after elution of the bromophenol blue. The fractions containing the peptides were identified by running every fourth fraction past the ion front on analytical PAGE. Once identified, the fractions of interest were desalted and concentrated on a Centricon Y M-10 or Ultrafree-15 unit (Millipore Corporation).

\section{Analytical SDS-PAGE and blotting}

Analytical SDS-PAGE was performed according to Laemmli (1970). Peptide separations were performed on $15 \%$ acrylamide gels. Depending on the experiments, gels were either fixed then colored with Coomassie blue, or fixed without any coloring when labeled peptides were to be analyzed, and then dried. Gels with labeled peptides were exposed to an imaging plate radioactive energy sensor (BAS-IP.MP 2040S; Fuji Photofilm Co. Ltd, Kamagawa, Japan). The exposed plate was analyzed using a phosphorimager (Fujix BAS 1000; Fuji). In another set of experiments, peptides were electrophoretically transferred from the polyacrylamide gel to a polyvinylidene difluoride (PVDF) membrane (ProBlott membrane; Applied Biosystems, Foster City, CA, USA). The transfer buffer contained $50 \mathrm{mM}$ Tris-base and $50 \mathrm{mM}$ boric acid. After transfer, the PVDF membrane was washed briefly with water, and the peptides were stained with amido black $(0 \cdot 1 \%$ in $45 \%$ methanol, $1 \%$ acetic acid) for a few seconds, washed with water and air-dried. Ultra-pure water was used throughout the blotting steps.

\section{Peptide sequencing}

After the blotting procedure, the peptides colored with amido black were cut off and sent for N-terminal amino acid sequencing to the Laboratoire de Microsequençage des Proteines at the Pasteur Institute (Paris, France).

\section{Iodination of peptides and proteins}

$\mathrm{hTg}$, IgG and peptides were iodinated with ${ }^{125} \mathrm{I}$ using the chloramine T method as described by Giraud et al. (1997).

\section{Binding and endocytosis experiments}

Binding and endocytosis experiments were performed as described by Giraud et al. (1997). Briefly, they were performed at $36^{\circ} \mathrm{C}$ under gentle agitation on suspended inside-out follicles (thyroid cells) or aggregates (MDCK or $\mathrm{CHO}$ cells). The incubations were started by adding labeled molecules: ${ }^{125} \mathrm{I}-\mathrm{hTg},{ }^{125} \mathrm{I}-\mathrm{hTg}$ peptides or ${ }^{125} \mathrm{I}-$ IgG $\left(1.5 \times 10^{-13} \mathrm{~mol} / \mathrm{ml}\right.$, with an assumed molecular weight (MW) of 330000 for Tg, 20000 for peptides P1 and $\mathrm{P} 2$ and 150000 for $\mathrm{IgG})$. They were ended $2 \mathrm{~h}$ later by careful cold washing in order to minimize non-specific binding evaluated as described by Giraud et al. (1997). A brief pronase treatment was carried out to separate the cell surface-associated material from the internalized material. For the competition experiments, unlabeled molecules were added to the incubation medium.

DNA was determined using the fluorimetric method described by Labarca \& Paigen (1980).

\section{Sequence comparisons}

Sequence comparisons were obtained from the SWISSPROT database and the results obtained with the SIM Program, through the Exposy Molecular Biology Server (proteomic server of the Swiss Institute of Bioinformatics).

\section{Results}

Identification of peptides from $\mathrm{hTg}$ that strongly bind cell surfaces

hTg peptides obtained by applying $\mathrm{CNBr}$ treatment to hypoiodinated $\mathrm{hTg}$ were fractionated on a Sephadex G-200 column as described by Marriq et al. (1986). Five fractions labeled I-V were collected. SDS-PAGE analysis of these fractions showed that each of them contained several peptides and that fractions III and IV showed fairly similar patterns (Fig. 1). The five fractions were

${ }^{125}$ I-labeled and their binding capacity on the cell surfaces 


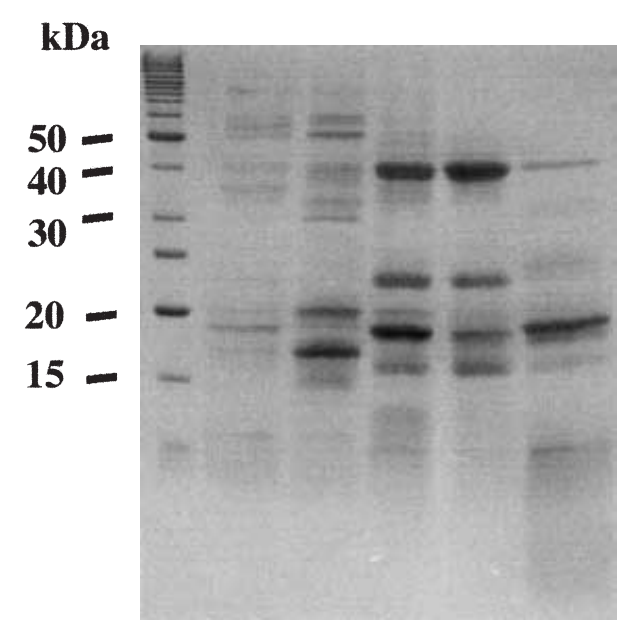

G 200 fractions I II III IV V

Figure 1 SDS-PAGE analysis of the $\mathrm{CNBr}$ peptides of $\mathrm{hTg}$ : $\mathrm{hTg}$ peptides obtained by $\mathrm{CNBr}$ treatment were fractionated on a Sephadex G-200 column, and five fractions labeled I-V were collected. Reduced samples of the five fractions were analyzed by $15 \%$ SDS-PAGE. After electrophoresis, the gel was stained with Coomassie blue. Lane I: fraction I peptides; lane II: fraction II peptides; lane III: fraction III peptides; lane IV: fraction IV peptides; lane $\mathrm{V}$ : fraction $\mathrm{V}$ peptides; left lane: molecular weight standards (Benchmark protein ladder; Gibco BRL).

was tested. They were all able to bind to the cell surfaces at both $\mathrm{pH} 7 \cdot 2$ and $8 \cdot 2$; the binding was slightly enhanced at $\mathrm{pH} 8 \cdot 2$, and fractions I, III and IV appeared to be the most efficiently bound (data not shown). We discarded fraction I, since it was the first fraction eluted from the G-200 column and was composed mainly of high molecular weight peptides unable to enter the gel in a $15 \%$ SDS-PAGE. To determine which peptides were bound to the cell surfaces, we incubated cells with labeled fractions II-V and studied the solubilized cell pellets by SDS-PAGE (whole cell pellets and pellets of pronase-treated cells). Three peptides present in fractions III and IV, with apparent MWs of about 18000 (P1), 22000 (P2) and 39000 (P3), were regularly associated with the thyroid cells (inside-out follicles) at both $\mathrm{pH} 7 \cdot 2$ and 8.2 (see Fig. 2 for cell-associated peptides from fraction III). P1, P2 and P3 were only weakly recovered if at all after pronase treatment, which indicates that they were mainly located at the surface. Other peptides with lower MWs were found in the cell pellets. But since they were still recovered after pronase treatment of the cells, they were probably degradation fragments of internalized peptides. P1, P2 and P3 were the main components of fractions III and IV. Since these peptides were present in high proportions in fraction III (see Fig. 1), this fraction was used afterwards in this study. When reduction and alkylation of fraction III were performed before the labeling and binding experiments, these peptides were still able to bind to the cell surfaces (Fig. 2a and b, lanes 3 and 4).

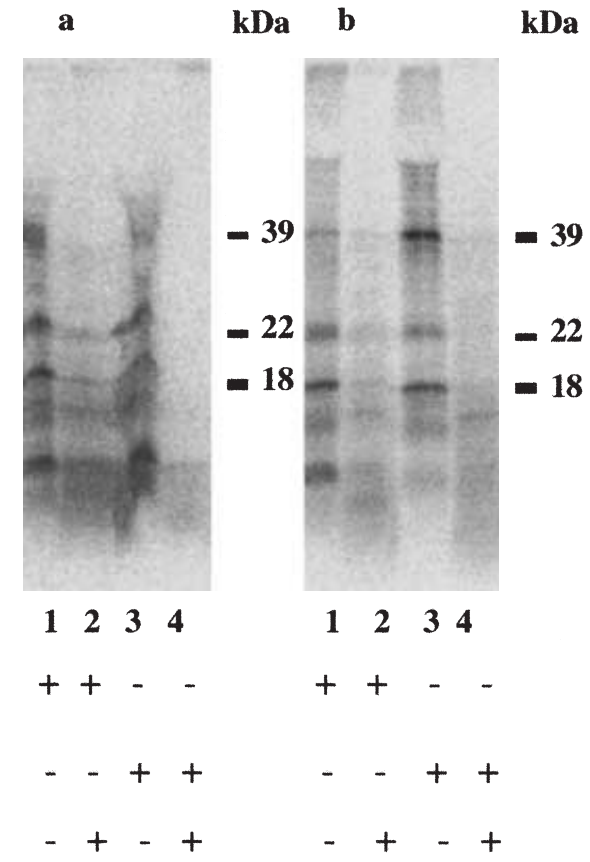

Native

Reduced and Alkylated

Pronase

-+ -

$-\quad+-+$

Figure 2 SDS-PAGE analysis of labeled peptides associated with thyroid cells: inside-out thyroid follicles were incubated with ${ }^{125}$ I-labeled fraction III peptides (lanes 1 and 2) or with ${ }^{125} \mathrm{I}$-labeled, reduced and alkylated fraction III peptides (lanes 3 and 4), at pH $7 \cdot 2$ (Fig. 3a), and pH $8 \cdot 2$ (Fig. 3b). After being incubated, the cells were subjected (lanes 2 and 4 ) or not (lanes 1 and 3) to a brief pronase treatment to remove all the cell surface-associated material. Cell pellets were then analyzed by SDS-PAGE. The labeled bands were revealed using a phosphorimager.

Using MDCK cells, we observed that these peptides were also associated with cell surfaces (Fig. 3) at both $\mathrm{pH} 7 \cdot 2$ and $8 \cdot 2$ : the binding of these peptides, like the binding of $\mathrm{Tg}$, was not tissue specific.

\section{Characterization of peptides with strong binding activity}

The reduced peptides from fraction III were separated by performing analytical SDS-PAGE and transferring them onto Pro Blott membranes. After blotting and amido black staining, we cut off and sequenced the three peptides of interest (those shown on Fig. 4). With two of the peptides, $\mathrm{P} 1$ and P2, four amino acids at the N-terminus, SSSQ for $\mathrm{P} 1$ and FYAD for P2 perfectly matched single fragments of the published hTg sequence; in addition, they occurred after a methionine, which fits the peptides obtained by $\mathrm{CNBr}$ cleavage. P3 was a mixture of several peptides. Two N-terminus fragments were identified: CSADYAGL for P3-1 and CSEENGGA for P3-2. Two other minor sequences recorded as being unsure did not match the published $\mathrm{Tg}$ sequences. The one was not identified; the other one (XSSEENDX) is present in the human asialoglycoprotein receptor 2. Given their apparent 


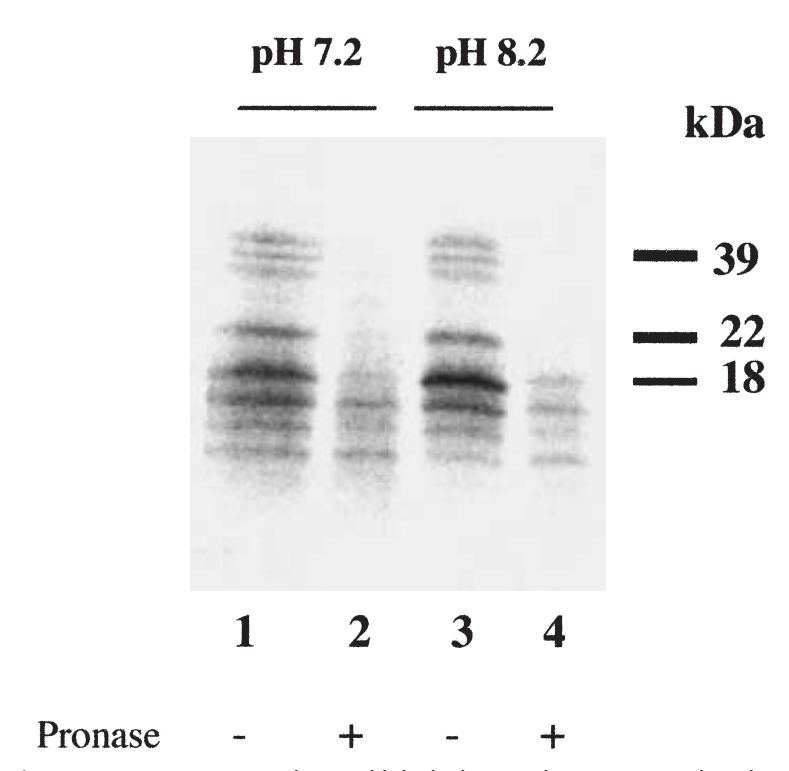

Figure 3 SDS-PAGE analysis of labeled peptides associated with MDCK cells: MDCK cells were incubated with ${ }^{125} \mathrm{I}$-labeled fraction III peptides at either $\mathrm{pH} 7 \cdot 2$ (lanes 1 and 2) or $\mathrm{pH} 8 \cdot 2$ (lanes 3 and 4). The cells were either subjected (lanes 2 and 4) or not (lanes 1 and 3 ) to a brief pronase treatment to remove all the cell surface-associated material. Cell pellets were then analyzed by SDS-PAGE. The labeled bands were revealed using a phosphorimager.

$\mathrm{MW}$, we can assume that $\mathrm{P} 1$ is the $\mathrm{Tg}$ fragment comprised between Ser-2445 and Met-2596 or Met-2610 (Met-2596 and Met-2610 are too closely spaced to choose between them on the basis of the apparent MW of P1) and that P2 is the Tg fragment comprised between Phe-2156 and Met-2306. P3-1 is the $\mathrm{Tg}$ fragment comprised between Cys-1306 and Met-1640 and P3-2 is the Tg fragment comprised between Cys-2035 and Met-2413 (see Fig. 5). P3-1 holds a central position and includes the type 2 repeats. P3-2 overlaps with part of the type 3 repeat and the beginning of the homology with acetylcholinesterase (ACHE) and includes P2 (Fig. 5). The inclusion of P2 in P3-2 would explain the binding properties of this peptide III fraction.

The heavier surface-bound peptides (peptides 3) were not good candidates for determining small binding domains on the $\mathrm{Tg}$ molecules, whereas the smallest surface-bound peptides clearly identified, P1 and P2, could enable us to identify binding domain(s) of limited size on the $\mathrm{Tg}$ molecule. They were purified by preparative electrophoresis and then used for the binding and internalization experiments.

\section{Structural information about P1 and P2 deduced from their sequences}

$\mathrm{P} 1$ and P2 are located entirely (P1) or partly (P2) in the non-repetitive $\mathrm{C}$-terminal region of $\mathrm{Tg}$, which is

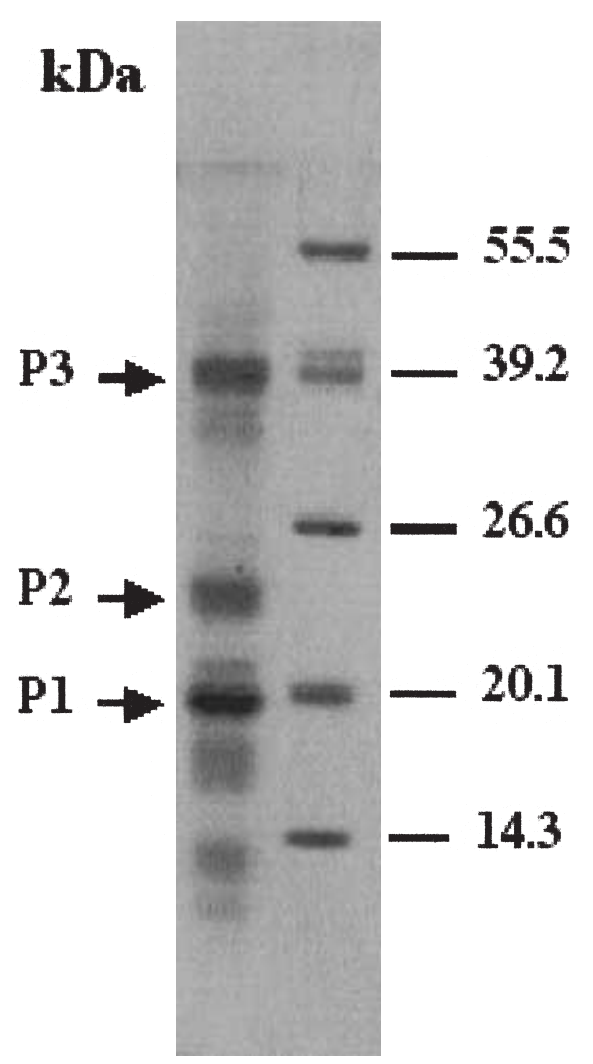

Figure 4 SDS-PAGE analysis of fraction III peptides. (Reducing conditions; Coomassie blue staining.) Left lane, fraction III peptides; right lane, molecular weight markers. The arrows point to the peptides of interest sequenced after blotting.

homologous with ACHE. P1 is 152 or 166 amino acids long, has a theoretical pI of 5.9, one potential glycosylation site at Asn-2582, two cysteines, Cys-2453 and Cys-2591, and a hormonogenic site, Tyr-2573. P2 is 151 amino acids long, has a theoretical pI of $8 \cdot 4$, two potential glycosylation sites, Asn-2250 and Asn-2295, and two cysteines, Cys-2264 and Cys-2281. The corresponding cysteines in the ACHE sequence form a disulfide bridge.

P1 and P2 sequences are well conserved between species. The identity between mouse and human sequences, which amounts to $73.8 \%$ in the case of the whole molecule, reaches $86.7 \%$ in $\mathrm{P} 1$ and $69 \%$ in $\mathrm{P} 2$. The identity between bovine and human sequences, which amounts to $77 \cdot 4 \%$ in the case of the whole molecule, reaches $83.6 \%$ in $\mathrm{P} 1$ and $82.6 \%$ in $\mathrm{P} 2$, which indicates that $\mathrm{P} 1$ is an extremely well-conserved Tg fragment and P2 a well-conserved one.

\section{Functional properties of $\mathrm{P} 1$ and $\mathrm{P} 2$}

Experiments were performed with the purified peptides, to check their binding and internalization ability and their 
MC C $^{1306}$ SADYAGLLQTFQVFILDELTARGFCQIQVKTFGTLVSIPVCNNSSVQVGCLTRERLGVNVTWKSRLEDIPVAS LPDLHDIERALVGKDLLGRFTDLIQSGSFQLHLDSKTFPAETIRFLQGDHFGTSPRTWFGCSEGFYQVLTSEASQDG LGCVKCPEGSYSQDEECIPCPVGFYQEQAGSLACVPCPVGRTTISAGAFSQTHCVTDCQRNEAGLQCDQNGQYRA SQKDRGSGKAFCVDGEGRRLPWWETEAPLEDSQCLMMQKFEKVPESKVIFDANAPVAVRSKVPDSEFPVMQCLT DCTEDEACSFFTVSTTEPEISCDFYAWTSDNVACM ${ }^{1640}$

C $^{2035}$ SEENGGAWRILDCGSPDIEVHTYPFGWYOKPI AQNNAPSFCPLVVLPSLTEKVSLDSWQSLALSSVVVDPSIRHFDVAHVSTAATSNFSAVRDLCLSECSQHEACLITTL QTQPGAVRCMF ${ }^{2156}$ YADTQSCTHSLQGQNCRLLLREEATHIYRKPGISLLSYEASVPSVPISTHGRLLGRSQAIQVGT SWKQVDQFLGVPYAAPPLAERRFQAPEPLNWTGSWDASKPRASCWQPGTRTSTSPGVSEDCLYLNVFIPQNVAP NASVLVFFHNTM ${ }^{200}$ DREESEGWPAIDGSFLAAVGNLIVVTASYRVGVFGFLSSGSGEVSGNWGLLDQVAALTWVQT HIRGFGGDPRRVSLAADRGGADVASIHLLTARATNSQLFRRAVLM ${ }^{2413}$ $\mathbf{S}^{2445}$ SSOEVVSCLROKPANVLNDAQTKLLAVSGPFHYWGPVIDGHFLREPPARALKRSLXVEVDLLIGSSQDDGLIN RAKAVKOFEESQGRTSSKTAFYQALQNSLGGEDSDARVEAAATWYYSLEHSTDDYASFSRALENATRDYFIICPIID MASAWAKRARGNVFM ${ }^{2610}$

Figure 5 Amino acid sequence and location of P1, P2, P3-1, and P3-2 on the Tg chain. P1: Ser-2445 to Met-2596 or Met-2610 (bold, black); P2: Phe-2156 to Met-2306 (bold, black); P 3-1: Cys-1306 to Met-1640 (bold, black); P 3-2: Cys-2035 to Met-2413 (bold, black). The homology with ACHE is underlined.

involvement in the binding of the whole $\mathrm{Tg}$ molecule to the apical surfaces of thyroid cells (inside-out follicles).

Binding and internalization of ${ }^{125} \mathrm{I}$-labeled $\mathrm{hTg}, \mathrm{P} 1$ and P2 Once purified, P1 and P2 were ${ }^{125}$ I-labeled and used in the binding and internalization experiments, along with ${ }^{125}$ I-labeled hTg (Fig. 6). These experiments were performed on thyroid cells (inside-out follicles). The hTg used was the hTg from which peptides $\mathrm{P} 1$ and $\mathrm{P} 2 \mathrm{had}$ been purified.

There was more cell surface-associated hTg than IgG at both $\mathrm{pH} 7 \cdot 2$ (Fig. 6a) and $8 \cdot 2$ (Fig. 6b), with a very clear-cut enhancement at $\mathrm{pH} 8 \cdot 2$; and there was more internalized $\mathrm{Tg}$ than IgG at both $\mathrm{pH}$ levels (Fig. 6a and b): the binding and internalization behavior of $\mathrm{hTg}$ is similar to that of porcine Tg described by Giraud et al. (1997).

The binding and internalization behavior of ${ }^{125}$ I-labeled peptides $\mathrm{P} 1$ and $\mathrm{P} 2$ were compared with that of ${ }^{125} \mathrm{I}$ labeled hTg. At pH 7·2, P1 and P2 bound to cell surfaces and were internalized more efficiently than Tg; indeed, many more peptides were detected inside the cells (Fig. 6a). At pH 8.2, there were slightly less surfaceassociated peptides than surface-associated $\mathrm{Tg}$, although there were more peptides than Tg inside the cell (Fig. 6b).

Effects of unlabeled peptides on binding and internalization of ${ }^{125} \mathrm{I}$-labeled $\mathrm{hTg}, \mathrm{P} 1$ and $\mathrm{P} 2$ As shown in Fig. 7, the presence of about $3.9 \times 10^{-6} \mathrm{M}$ unlabeled $\mathrm{P} 1$ or $\mathrm{P} 2$ decreased the amount of ${ }^{125} \mathrm{I}$-labeled $\mathrm{hTg}$

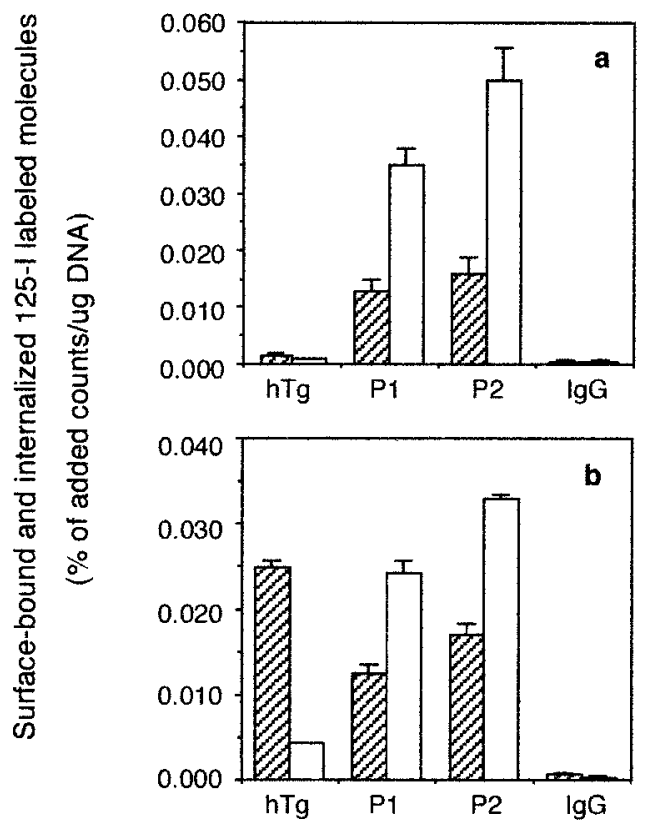

Figure 6 Binding and internalization of ${ }^{125} \mathrm{I}$-labeled hTg, P1, P2 and IgG by thyroid cells (inside-out follicles). (a) $\mathrm{pH} 7 \cdot 2$ and (b) $\mathrm{pH} 8 \cdot 2$. Cell surface-associated label, hatched bars; internalized label, open bars. Results are expressed as the mean \pm S.D. of the percentage of added counts recovered normalized for the amount of DNA detected in each sample (three experiments). 


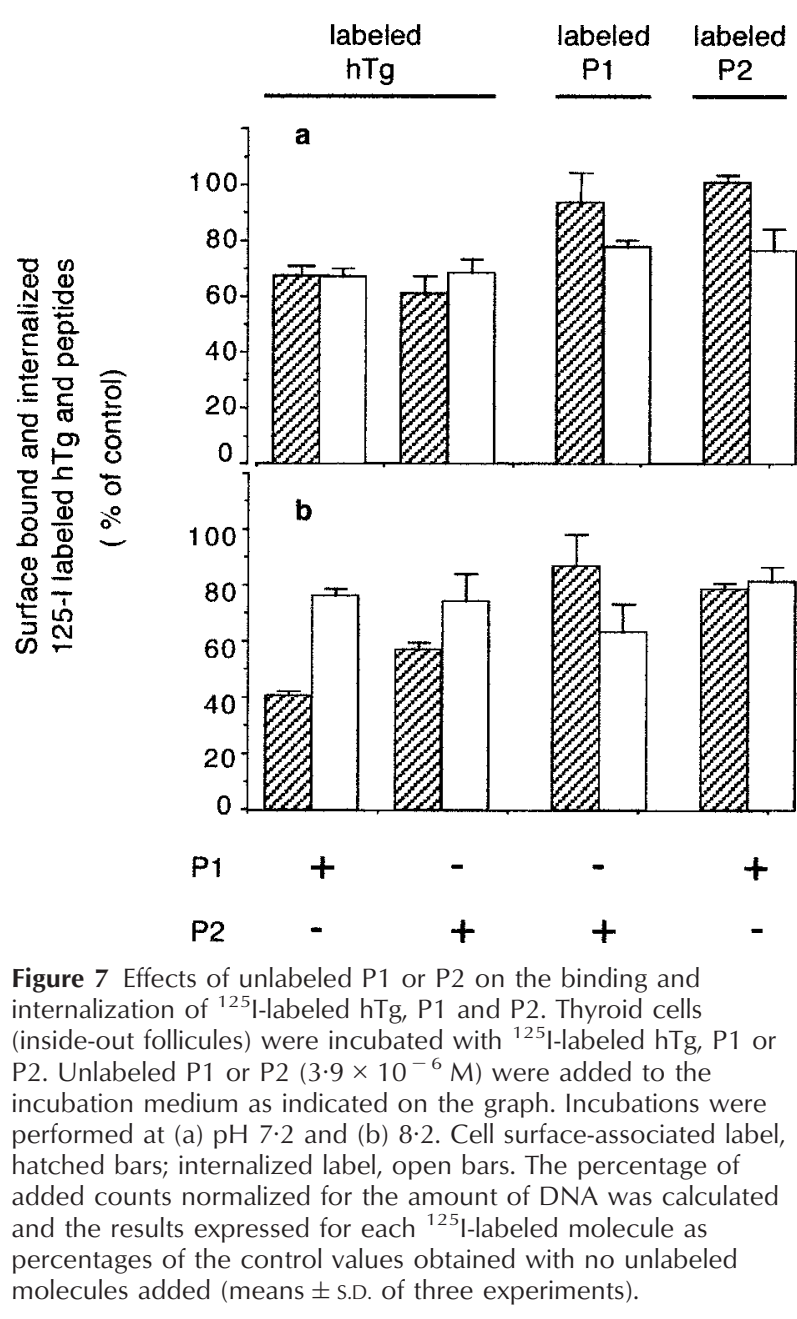

binding to the thyroid apical surface $\left(3.9 \times 10^{-6} \mathrm{M}\right.$ is the unlabeled $\mathrm{Tg}$ concentration that gives the maximum $(95 \%)$ inhibition of ${ }^{125}$ I-labeled hTg binding (data not shown)). With $\mathrm{P} 1$, a stronger decrease was observed at $\mathrm{pH}$ $8 \cdot 2$ (Fig. 7b) than at pH 7.2 (Fig. 7a) (about 60\% decrease versus about $30 \%$ ). With $\mathrm{P} 2$, a fairly similar decrease of about $40 \%$ was observed at both $\mathrm{pH}$ levels. Internalization was also decreased to the same level (about 30\%) with all the peptides tested, at both $\mathrm{pH}$ levels.

The proximity of $\mathrm{P} 1$ and $\mathrm{P} 2$ on the $\mathrm{Tg}$ sequence prompted us to check whether they were different binding domains of $\mathrm{Tg}$, or parts of the same one. We carried out binding competition experiments between the two peptides. The binding of ${ }^{125}$ I-labeled P1 to inside-out follicles was almost unaffected by the presence of $3.9 \times 10^{-6} \mathrm{M}$ unlabeled $\mathrm{P} 2$ at $\mathrm{pH} 7 \cdot 2$ (Fig. 7a), and a slight decrease (about 10\%) was observed at $\mathrm{pH} 8 \cdot 2$ (Fig. 7b). The binding of ${ }^{125}$ I-labeled P2 to inside-out follicles was almost unaffected by the presence of $3.9 \times 10^{-6} \mathrm{M}$ unlabeled $\mathrm{P} 1$ at $\mathrm{pH} 7 \cdot 2$ (Fig. 7a), and a slight decrease (about 20\%) was observed at $\mathrm{pH} 8 \cdot 2$ (Fig. 7b). The amount of internalized labeled P1 or P2 was somewhat decreased by the presence of the unlabeled other peptide, especially at $\mathrm{pH} 8 \cdot 2$.

\section{Binding and internalization of ${ }^{125} \mathrm{I}$-labeled $\mathrm{hTg}, \mathrm{P} 1$ and P2 on non-thyroid cells}

Binding and internalization are non-tissue specific properties of $\mathrm{Tg}$ but intrinsic properties of this protein. If any binding of Tg to non-thyroid cells occurred via P1 and P2, the binding and internalization of the peptides should not be tissue specific. To test this hypothesis, binding and internalization of ${ }^{125} \mathrm{I}$-labeled $\mathrm{hTg}, \mathrm{P} 1$ and $\mathrm{P} 2$ were performed with MDCK cells (Fig. 8a and b) and $\mathrm{CHO}$ cells (Fig. 8c and d). As previously observed with thyroid cells, there was more cell surface-associated $\mathrm{Tg}$ than $\operatorname{IgG}$ at both $\mathrm{pH} 7 \cdot 2$ and 8.2. At $\mathrm{pH} 7 \cdot 2$ (Fig. $8 \mathrm{a}$ and $\mathrm{c}$ ), $\mathrm{P} 1$ and $\mathrm{P} 2$ bound to the cell surfaces and were internalized more efficiently than Tg. In fact, many more peptides were observed inside the cells, as was previously found to be the case with thyroid cells. At pH 8.2 (Fig. $8 \mathrm{~b}$ and d), there were less surface-associated peptides than surfaceassociated $\mathrm{Tg}$, as observed with thyroid cells. The amount of internalized label was greater than the amount of surface label in MDCK cells (Fig. 8b), as observed with thyroid cells, but less than the surface label in $\mathrm{CHO}$ cells (Fig. 8d).

\section{Discussion}

In a previous work (Giraud et al. 1997) we showed that Tg binding to the apical surface of thyroid inside-out follicles occurs through numerous sites considered non-specific on account of their low affinity, while at $\mathrm{pH} 8 \cdot 2$ specific sites of moderate affinity appeared, contributing to a strengthened binding. In addition, at both $\mathrm{pH}$ values, $\mathrm{Tg}$ binding was selective relative to the binding of other molecules. Also these binding properties were not restricted to thyroid tissue. The main role of $\mathrm{Tg}$ binding and endocytosis is lysosomal degradation and hormone release, although other functions, involving 'receptors', have been described (Ulianich et al. 1999, Marino et al. 2000, Mezghrani et al. 2000). Tg is the main component of the follicular lumen and is present at very high concentrations. This is a strong argument in favor of a massive endocytosis occurring via low affinity receptors. But the nature of these receptors is still unknown, and the size of the Tg molecule, plus the fact that it recognizes different receptors via various specialized domains, mean that it cannot be used to identify the receptors involved in lysosomal degradation.

In the present study, our aim was to identify $\mathrm{Tg}$ fragments involved in the low and moderate affinity binding of $\mathrm{Tg}$ previously described. So we looked for $\mathrm{Tg}$ fragments able to bind cell surfaces and to hinder Tg binding to those same cell surfaces. We identified and 


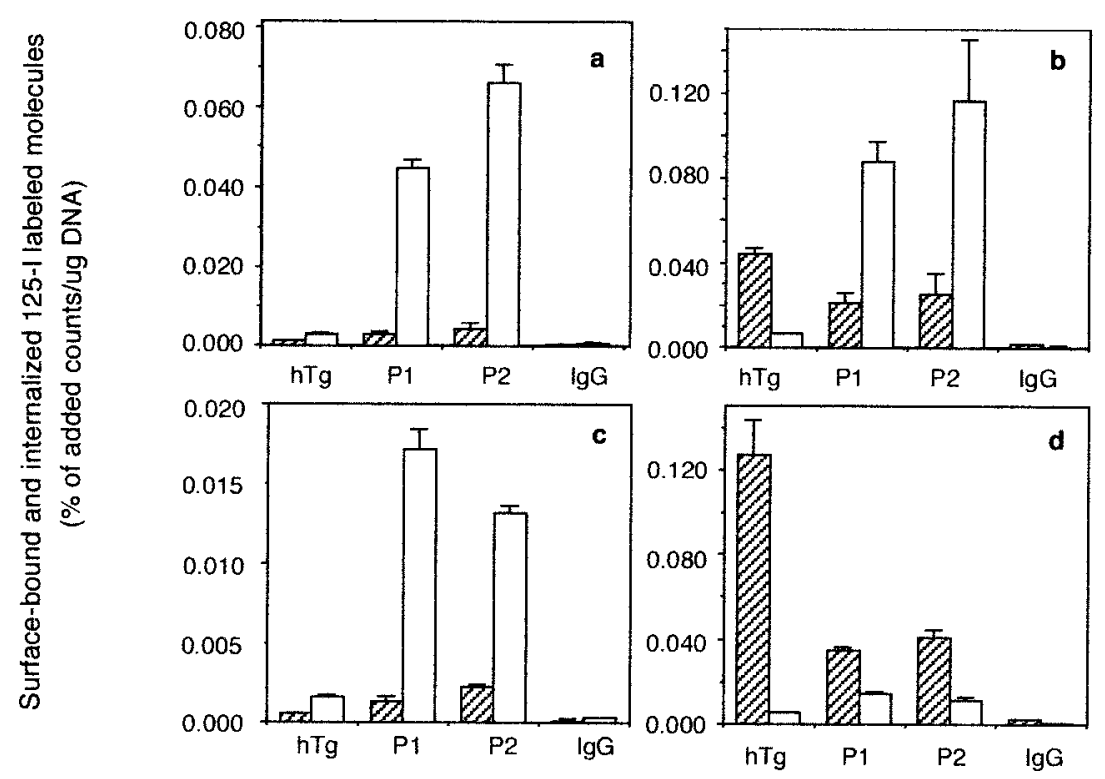

Figure 8 Binding and internalization of ${ }^{125} \mathrm{I}$-labeled $\mathrm{hTg}, \mathrm{P} 1, \mathrm{P} 2$ and $\operatorname{lgG}$ by MDCK cells and $\mathrm{CHO}$ cells. (a) MDCK cells, $\mathrm{pH} 7 \cdot 2$; (b) MDCK cells, $\mathrm{pH} 8 \cdot 2$; (c) $\mathrm{CHO}$ cells, $\mathrm{pH} 7 \cdot 2$; (d) $\mathrm{CHO}$ cells, $\mathrm{pH} 8 \cdot 2$. Cell surface-associated label, hatched bars; internalized label, open bars. Results are expressed as means \pm S.D. of the percentage of added counts recovered normalized for the amount of DNA detected in each sample (three experiments).

purified two hTg peptides, P1 and P2, that fit these criteria. P1 and P2 are both able to bind cell surfaces and to partially and independently inhibit whole Tg binding. They are both located either entirely (P1) or partly (P2) in the non-repetitive C-terminal region of $\mathrm{Tg}$ which is homologous with ACHE. Experiments performed with the purified peptides showed that at both $\mathrm{pH} 7 \cdot 2$ and $\mathrm{pH}$ 8.2, P1 and P2 bind to cell surfaces of inside-out thyroid follicles and are internalized (Fig. 6). The greater level of internalization of $\mathrm{P} 1$ and $\mathrm{P} 2$ relative to $\mathrm{Tg}$ may be due to an enhanced endocytosis and/or to a lack of recycling once the peptides are inside the cells: P1 and P2 lack the $\mathrm{Tg}$ recycling receptor that binds to $\mathrm{Tg}$ via a peptide (N3) located in the first half of the $\mathrm{Tg}$ molecule (Mezghrani et al. 1997). In addition, recycling of the cell surfacebinding sites could modulate the binding level and contribute to the actual ligand distribution between cell surface and internal compartments. The increase in the Tg-binding level observed previously at $\mathrm{pH} 8.0$ as compared with pH 7.2 (Giraud et al. 1997) may be partly due to a change in the $\mathrm{Tg}$ conformation, facilitating access to these peptides on the Tg molecule, and/or to some ionic modification of the peptides themselves. The reduction and alkylation of the peptides do not prevent the binding of $\mathrm{P} 1$ and $\mathrm{P} 2$ from occurring, which indicates that the binding process does not require the disulfide bridge that may possibly exist in hTg between Cys-2264 and Cys-2281 in P2 (by analogy with ACHE). The cysteines present in P1 (Cys-2453 and Cys-2591) are not likely to form a disulfide bridge inside P1, but might be involved in the formation of disulfide bridges in the hTg molecule, with Cys-2442 and Cys-2712 respectively (by analogy with ACHE). These disulfide bridges, if present, are not necessary to the binding process. P1 and P2 inhibit Tg binding: a neat but moderate inhibition was observed at $\mathrm{pH} 7.2$ and a stronger one at $\mathrm{pH} 8.2$ (Fig. 7). This indicates that $\mathrm{P} 1$ and $\mathrm{P} 2$ are $\mathrm{Tg}$ fragments involved in the binding of the whole $\mathrm{Tg}$ molecule. However, the fact that inhibition of $\mathrm{Tg}$ binding by the peptides is limited suggests that other low-affinity binding sites of $\mathrm{Tg}$ might be involved. And there is still the possibility that purified $\mathrm{Tg}$ peptide conformation is not quite what it was in the native $\mathrm{Tg}$ molecule. Crossed competition experiments showed that the binding of either labeled peptide is only poorly inhibited, if at all, by the presence of the unlabeled other one, which suggests that $\mathrm{P} 1$ and $\mathrm{P} 2$ bind independent sites on cell surfaces. However, the internalization process is somewhat inhibited under these conditions. Competition experiments require large quantities of purified peptides. The scarcity of these materials, when they are obtained by conventional methods, restricts the experimental possibilities. P1 and P2 will have to be produced by cloning the corresponding fragments of the $\mathrm{Tg}$ gene in order to perform complementary experiments. In the meantime, we have performed experiments to check the tissue specificity of P1 and P2 binding and internalization. Whole Tg binding and internalization are not tissue specific, so the $\mathrm{Tg}$ peptides that mediate $\mathrm{Tg}$ binding 
should not display tissue specificity when binding to cell surfaces. We found that $\mathrm{P} 1$ and $\mathrm{P} 2$ are able to bind to non-thyroid cell surfaces and are internalized by these cells. This further suggests that $\mathrm{Tg}$ binding occurs through P1 and P2. However, the rather low internalized label observed in $\mathrm{CHO}$ cells might reflect some subtle tissue difference(s) not observed previously with whole Tg.

Peptides other than P1 and P2 could be able to bind to cell surfaces and to hinder Tg binding to these same cell surfaces. We had the opportunity to test the properties of several purified $\mathrm{Tg}$ peptides disposed at various places along the molecule: the $\mathrm{N}$-terminal domain of Tg (Marriq et al. 1986), two type 1 repeats (a kind gift from Dr R Miquelis), the N3 peptide (a kind gift from $\mathrm{Dr} R$ Miquelis), which binds to the recycling $\mathrm{Tg}$ receptor (Mezghrani et al. 1997) and an immunoreactive $\mathrm{Tg}$ peptide P40 (of about $40 \mathrm{kDa}$ ) (Duthoit et al. 2000) (a kind gift from Dr J Ruf) produced during the hTg oxidative process, located at the $\mathrm{C}$-terminal end of the molecule and including P1. All these peptides but one possess only very limited binding capabilities (results not shown). Indeed, the N3 peptide binds almost as efficiently to cell surfaces as $\mathrm{Tg}$ does. However, it fails to inhibit the Tg binding, which suggests that this part of the $\mathrm{Tg}$ molecule is not involved in the binding process at non-acidic $\mathrm{pH}$ levels. By contrast, the peptide P40 (which includes P1) displays binding and internalization capacities that match those of P1 and P2. However, with their smaller size (about $20 \mathrm{kDa}$ ), P1 and P2 constitute more limited binding domains on the Tg molecule and are better potential tools for identifying cell surface Tg-binding molecules. Among all the purified $\mathrm{Tg}$ peptides tested, only those located entirely or partly in the non-repetitive C-terminal domain of $\mathrm{Tg}$ express cell surface-binding capacity. The published sequences of $\mathrm{Tg}$ show good homology between human, bovine and murine species, and this homology increases if we consider only P1. With P2, the homology slightly decreases between man and mouse but is very marked between man and bull. The very good sequence conservation between species in P1 might be partly related to the presence of a secondary hormonogenic site. But the good sequence conservation between species in the whole C-terminal domain suggests that it is involved in some useful function(s), one of which is probably its capacity to adhere to cell membranes.

Some $\mathrm{Tg}$ domains responsible for the $\mathrm{Tg}$ binding to some receptors were recently identified. They were either a large N-terminal Tg domain (Montuori et al. 2000) or a central Tg peptide (Mezghrani et al. 1997) and bear no resemblance to $\mathrm{P} 1$ or $\mathrm{P} 2$. However, the $\mathrm{Tg}$ domains responsible for megalin binding (Zheng et al. 1998, Marino et al. 1999b) have not yet been clearly identified. A heparin consensus sequence (SRRLKRP) involved in megalin binding was identified on rat $\mathrm{Tg}$ (Marino et al. 1999a). The corresponding sequence in hTg (ARALKRS) is part of P1. But here, a neutral amino acid, A, replaces a basic one, $\mathrm{R}$, and its binding capacity towards heparin is probably weaker in $\mathrm{hTg}$ than in rat $\mathrm{Tg}$. The corresponding sequence in bovine Tg (ARVLQRA) probably shows an even weaker binding ability to heparin, since two basic amino acids are replaced ( $\mathrm{R}$ by $\mathrm{V}$ and $\mathrm{K}$ by $\mathrm{Q}$ ). In our study, megalin was not involved in $\mathrm{Tg}$ binding to cell surfaces, since it is not detectable on CHO cells (Marino et al. 1999b), and since primary cultures of porcine thyroid cells cease to express megalin after a few days (Marino et al. 1999b). In addition, the low-affinity binding that occurs at $\mathrm{pH} 7 \cdot 2$ suggests that here $\mathrm{Tg}$ binds to still unidentified molecules other than megalin.

As previously stated (Giraud et al. 1997), $\mathrm{Tg}$ is a 'multireceptor' ligand. It is worth noting that most of the Tg 'receptors' described so far (megalin, PDI, heparin, H1 histones) are ubiquitous proteins, or at least molecules that are not restricted to thyroid tissue (rat hepatic lectin). Their role in Tg metabolism depends on the place where they encounter Tg, and on intrinsic Tg properties. Here we studied apical binding. Since we have previously established that the low-affinity binding of $\mathrm{Tg}$ is not tissue specific, and since a basolateral selective $\mathrm{Tg}$ binding of low affinity was demonstrated by Gire et al. (1996), it seems likely that the corresponding Tg-binding molecules will turn out to be ubiquitous molecules which occur widely on various cell surfaces. However, due to experimental constraints, the present study deals with molecules that do not need thyrotropin for their cell surface expression, and we cannot exclude the possibility that some additional low-affinity, TSH-dependent, Tg-binding molecule(s) contribute to $\mathrm{Tg}$ endocytosis in vivo.

In conclusion, we purified two peptides, P1 and P2, located in the C-terminal domain of Tg that are able to bind apical surfaces of thyroid cells and are internalized. The results of the inhibition experiments strongly suggested that they are involved in the Tg binding previously described (Giraud et al. 1997). They are different from the $\mathrm{Tg}$ peptides involved in Tg recycling (Mezghrani et al. 1997), in the feedback regulation which involves correlation between $\mathrm{Tg}$ binding and in the suppression of thyroid-restricted gene expression (Montuori et al. 2000) and are not involved in the transcytosis involving megalin binding (Marino et al. 2000). These findings suggest that $\mathrm{P} 1$ and $\mathrm{P} 2$ are potential tools for identifying the cell surface molecules involved in the Tg binding which occurs at low or moderate affinity sites, and will help to understand the pathways mediating lysosomal degradation and hormone release.

\section{Acknowledgements}

S S-F and F D were supported by the Association pour le Developpement des Recherches Biologiques et Medicales. We thank Dr R Miquelis, Laboratoire de Biochimie, UMR 6560, Faculté de Médecine-Nord, Marseille, 
France, for supplying type 1 repeats and N3 peptide from hTg, and Dr J Ruf, Inserm U 555, Faculté de Médecine, Marseille, France, for supplying P40 peptide from hTg. We thank Philippe Conte for his help in preparing the Figures.We thank Professor Pierre Carayon for useful advice and help in the preparation of the manuscript.

\section{References}

Bjorkman U \& Ekholm R 1990 Biochemistry of thyroid hormone formation and secretion. In The Thyroid Gland pp 83-125. Ed. MA Greer. New York: Raven Press.

Brix K, Summa W, Lottspeich F \& Herzog V 1998 Extracellularly occurring histone $\mathrm{H} 1$ mediates the binding of thyroglobulin to the cell surface of mouse macrophages. Journal of Clinical Investigation 102 283-293.

Caturegli P, Vidalain PO, Vali M, Aguilera-Galaviz LA \& Rose NR 1997 Cloning and characterization of murine thyroglobulin cDNA Clinical Immunology and Immunopathology 85 221-226.

Chambard M, Gabrion J \& Mauchamp J 1981 Influence of collagen gel on the orientation of epithelial cell polarity: follicle formation from isolated thyroid cells and from preformed monolayers. Journal of Cell Biology 91 157-166.

Consiglio E, Shifrin S, Yavin Z, Ambesi-Impiombato FS, Rall JE, Salvatore G \& Kohn LD 1981 Thyroglobulin interactions with thyroid membranes. Relationship between receptor recognition of $\mathrm{N}$-acetylglucosamine residues and the iodine content of thyroglobulin preparations. Journal of Biological Chemistry 256 10592-10599.

Duthoit C, Estienne V, Delom F, Durand-Gorde JM, Mallet B, Carayon P \& Ruf J 2000 Production of immunoreactive thyroglobulin C-terminal fragments during thyroid hormone synthesis. Endocrinology $1412518-2525$.

Espanet H, Alquier C \& Mauchamp J 1992 Polarity reversal of inside-out thyroid follicles cultured on the surface of a reconstituted basement membrane matrix. Experimental Cell Research 200 473-480.

Giraud A, Siffroi S, Lanet J \& Franc JL 1997 Binding and internalization of thyroglobulin: selectivity, $\mathrm{pH}$ dependence and lack of tissue specificity. Endocrinology 138 2325-2332.

Gire V, Kostrouch Z, Bernier-Valentin F, Rabilloud R, Munari-Silem Y \& Rousset B 1996 Endocytosis of albumin and thyroglobulin at the basolateral membrane of thyrocytes organized in follicles. Endocrinology 137 522-532.

Labarca C \& Paigen K 1980 A simple, rapid, and sensitive DNA assay procedure. Analytical Biochemistry 102 344-352.

Laemmli UK 1970 Cleavage of structural proteins during the assembly of the head of bacteriophage T4. Nature 227 680-685.

Lemansky P \& Herzog V 1992 Endocytosis of thyroglobulin is not mediated by mannose-6-phosphate receptors in thyrocytes. Evidence for low-affinity-binding sites operating in the uptake of thyroglobulin. European Journal of Biochemistry 209 111-119.

Malthiery Y \& Lissitzky S 1987 Primary structure of human thyroglobulin deduced from the sequence of its 8448-base complementary DNA. European Journal of Biochemistry 165 491-498.

Marino M \& McCluskey RT 2000 Megalin mediated transcytosis of thyroglobulin by thyroid cells is a calmodulin-dependent process. Thyroid 10 461-469.

Marino M, Friedlander JA, McCluskey RT \& Andrews D 1999a Identification of a heparin-binding region of rat thyroglobulin involved in megalin binding. Journal of Biological Chemistry 274 30377-30386.

Marino M, Zheng G \& McCluskey RT 19996 Megalin (gp 330) is an endocytic receptor for thyroglobulin on cultured Fisher rat thyroid cells. Journal of Biological Chemistry 274 12898-12904.
Marino M, Zheng G, Chiovato L, Pinchera A, Brown D, Andrews D \& McCluskey RT 2000 Role of megalin (gp 330) in transcytosis of thyroglobulin by thyroid cells. Journal of Biological Chemistry 275 7125-7137.

Marriq C, Rolland M \& Lissitzky S 1977 Polypeptide chains of 19-S thyroglobulin from several mammalian species and of porcine 27-S iodoprotein. European Journal of Biochemistry 79 143-149.

Marriq C, Lejeune PJ, Venot N, Rolland M \& Lissitzky S 1986 Characterization of a hormonogenic domain from human thyroglobulin. FEBS Letters 207 302-306.

Mercken L, Simmons MJ, Swillens S, Massaer M \& Vassart G 1985 Primary structure of bovine thyroglobulin deduced from the sequence of its 8431-base complementary DNA. Nature 316 647-651.

Mezgrhani H, Mziaut H, Courageot J, Oughideni R, Bastiani P \& Miquelis R 1997 Identification of the membrane receptor binding domain of thyroglobulin. Journal of Biological Chemistry 272 23340-23346.

Mezghrani A, Courageot J, Mani J C, Pugniere M, Bastiani P \& Miquelis R 2000 Protein-disulfide isomerase (PDI) in FRTL5 cells. $\mathrm{pH}$-dependent thyroglobulin/PDI interactions determine a novel PDI function in the post-endoplasmic reticulum of thyrocytes. Journal of Biological Chemistry 275 1920-1929.

Miquelis R, Alquier C \& Monsigny M 1987 The N-acetylglucosaminespecific receptor of the thyroid. Binding characteristics, partial characterization and potential role. Journal of Biological Chemistry 262 15291-15298.

Molina F, Bouanani M, Pau B \& Granier C 1996a Characterization of the type-1 repeat from thyroglobulin, a cysteine-rich module found in proteins from different families. European Journal of Biochemistry $240125-133$

Molina F, Pau B \& Granier C $1996 b$ Hypothesis. the type-1 repeats of thyroglobulin regulate thyroglobulin degradation and $\mathrm{T} 3, \mathrm{~T} 4$ release in thyrocytes. FEBS Letters 391 229-231.

Montuori N, Pacifico F, Mellone S, Liguoro D, Di Jeso B, Formisano S, Gentile F \& Consiglio E 2000 The rat asialoglycoprotein receptor binds the amino-terminal domain of thyroglobulin. Biochemical and Biophysical Research Communications 268 42-46.

Pacifico F, Liguoro D, Acquaviva R, Formisano S \& Consiglio E 1999 Thyroglobulin binding and TSH regulation of the RHL-1 subunit of the asialoglycoprotein receptor in rat thyroid. Biochimie 81 493-496.

Swillens S, Ludgate M, Mercken L, Dumont JE \& Vassart G 1986 Analysis of sequence and structure homologies between thyroglobulin and acetylcholinesterase: possible functional and clinical significance. Biochemical and Biophysical Research Communications 137 142-148.

Takagi Y, Omura T \& Go M 1991 Evolutionary origin of thyroglobulin by duplication of esterase gene. FEBS Letters $\mathbf{2 8 2}$ $17-22$.

Ulianich L, Suzuki K, Mori A, Nakazato M, Pietrarelli M, Goldsmith P, Pacifico F, Consiglio E, Formisano S \& Kohn L 1999 Follicular thyroglobulin (TG) suppression of thyroid-restricted genes involves the apical membrane asialoglycoprotein receptor and TG phosphorylation. Journal of Biological Chemistry 274 25099-25107.

Van de Graaf SAR, Pauws E, De Viljlder JMM \& Ris-Stalpers C 1997 The revised 8307 base pair coding sequence of human thyroglobulin transiently expressed in eukaryotic cells. European Journal of Endocrinology 136 508-515.

Zheng G, Marino M, Zhao J \& McCluskey RT 1998 Megalin (gp 330): a putative endocytic receptor for thyroglobulin. Endocrinology 139 1462-1465.

Received 8 December 2000 Accepted 7 March 2001 